\title{
Response of five temperate deciduous tree species to water stress
}

\author{
T. G. RANNEY, ${ }^{1}$ T. H. WHITLOW ${ }^{2}$ and N. L. BASSUK ${ }^{2}$ \\ ${ }^{1}$ Mountain Horticultural Crops Research and Extension Center, Department of Horticultural \\ Science, North Carolina State University, 2016 Fanning Bridge Road, Fletcher, NC 28732, USA \\ 'Department of Floriculture and Ornamental Horticulture, Cornell Univer sity, Ithaca, NY 14853, USA
}

Received October 23, 1989

\begin{abstract}
Summary
Gas exchange, tissue water relations, and leaf/root dry weight ratios were compared among young, container-grown plants of five temperate-zone, deciduous tree species (Acer negundo L., Betula papyrifera Marsh, Malus baccata Borkh, Robinia pseudoacacia L., and Ulmus parvifolia Jacq.) under well-watered and water-stressed conditions. There was a small decrease (mean reduction of $0.22 \mathrm{MPa}$ across species) in the water potential at which turgor was lost $\left(\Psi_{\text {tlp }}\right)$ in response to water stress. The $\Psi_{\text {tlp }}$ for water-stressed plants was $-1.18,-1.34,-1.61,-1.70$, and $-2.12 \mathrm{MPa}$ for $B$. papyrifera, A. negundo, $U$. parvifolia, $R$. pseudoacacia, and $M$. baccata, respectively. Variation in $\Psi_{\mathrm{tlp}}$ resulted primarily from differences in tissue osmotic potential and not tissue elasticity. Rates of net photosynthesis declined in response to water stress. However, despite differences in $\Psi_{\text {tlp }}$, there were no differences in net photosynthesis among water-stressed plants under the conditions of water stress imposed. In A. negundo and $M$. baccata, water use efficiency (net photosynthesis/transpiration) increased significantly in response to water stress. Comparisons among water-stressed plants showed that water use efficiency for $M$. baccata was greater than for $B$. papyrifera or $U$. parvifolia. There were no significant differences in water use efficiency among $B$. papyrifera, $U$. parvifolia, $A$. negundo, and $R$. pseudoacacia. Under water-stressed conditions, leaf /root dry weight ratios (an index of transpiration to absorptive capacity) ranged from 0.77 in $R$. pseudoacacia to 1.05 in B. papyrifera.
\end{abstract}

\section{Introduction}

The ability of plants to survive and grow on dry sites varies among species. For example, Robinia pseudoacacia L. (Bunger and Thomson 1938), Ulmus parvifolia Jacq. (Dirr and Richards 1989), Malus spp. (Lakso 1983, Flint 1985), and Acer negundo L. (Hatton 1935, Dewers 1981) are reported to be relatively tolerant of dry sites compared to other temperate, deciduous tree species. In contrast, Betula papyrifera Marsh appears to be intolerant of dry sites (Pomerleau and Lortie 1962).

A plant's capacity to resist drought depends on a variety of adaptive characteristics and mechanisms (Turner 1979, Jones 1980). Based on the classification system presented by Turner (1979), these adaptations may enable plants either to maintain high tissue water potentials $\left(\Psi_{\mathrm{w}}\right)$ during drought or to increase their tolerance of low plant water potentials.

The purpose of this study was to compare leaf gas exchange, leaf/root dry weight ratios, and the capacity to maintain turgor at low tissue water potentials in five deciduous tree species under both well-watered and water-stressed conditions. 


\section{Materials and methods}

\section{Plant material}

Bare-root seedlings of Acer negundo (box elder), Malus baccata Borkh (Siberian crabapple), (Robinia pseudoacacia (black locust), Ulmus parvifolia (Chinese elm), and Betula papyrifera (paper birch), ranging in height from 45 to $60 \mathrm{~cm}$, were pruned to a single stem $25 \mathrm{~cm}$ above the root crown. Root systems were pruned to a maximum length of $20 \mathrm{~cm}$ below the crown.

On May 3, 1988, plants were potted in 19-liter white plastic containers filled with a pasteurized mixture of vermiculite/sphagnum peat moss/soil $(1 / 1 / 1 / \mathrm{v} / \mathrm{v})$. Before the irrigation treatments were begun, plants were grown outside in Ithaca, NY under natural conditions for 16 weeks. They were kept well-watered and fertilized weekly with a $10 / 10 / 10, \mathrm{~N} / \mathrm{P}_{2} \mathrm{O}_{5} / \mathrm{K}_{2} \mathrm{O}$ solution containing $\mathrm{N}$ at a concentration of $200 \mathrm{mg} \mathrm{l}^{-1}$. For the experiment, the plants were moved to a glass greenhouse and the irrigation treatments begun on August 22, 1988, at which time plants were similar in size, with a mean total shoot length of $307 \mathrm{~cm}$.

\section{Irrigation treatments}

The experiment was a two-way factorial (five species $\times$ two irrigation treatments) randomized complete block design with eight replications per treatment. The control (well-watered) plants of each species were irrigated every evening to container through-flow, whereas the plants subjected to water stress were irrigated with only sufficient water to restore a container weight corresponding to a bulk soil water potential of $-1.1 \mathrm{MPa}$, based on a soil water release curve. This irrigation regime can result in some variation in soil water content within a container at certain times, but it makes it possible to subject a number of plants to similar amounts of water stress for extended periods of time. The degree of water stress imposed was chosen to provide a bulk soil water potential above the turgor loss point reported for most temperate-zone deciduous tree species. Treatments were imposed for 30 days.

\section{Plant water relations}

Tissue water potential was determined with a pressure chamber (Plant Moisture Status Console, Soilmoisture Equipment Corp., Santa Barbara, CA). Tissue water relations were determined during the last 10 days of the 30-day cxpcriment using pressure-volume methodology (Tyree and Hammel 1972). Samples were collected and measurements taken on a block by block basis. Because of the small leaf size of $U$. parvifolia, terminal shoots $(12 \mathrm{~cm}$ long) with 8 to 10 leaves were used for pressure-volume measurements. Fully exposed sun-leaves ( 5 th most recently fully expanded lcaf) wcrc uscd for all other species. Samples were collected before dawn, re-cut under water, enclosed in a polyethylene bag, placed in the dark, and allowed to rehydrate for $2 \mathrm{~h}$. Tissue water potentials and corresponding leaf weights were then measured periodically on each sample over a range of tissue water potentials from 0 to $-4.0 \mathrm{MPa}$. Between measurements, samples were allowed to transpire freely 
outside the pressure chamber (Hinckley et al. 1980, Ritchie and Roden 1985). A gas mixture of $98 \% \mathrm{~N}_{2}$ and $2 \% \mathrm{O}_{2}$ was used to pressurize the chamber. The chamber pressure was changed at a rate not exceeding $0.02 \mathrm{MPa} \mathrm{s}^{-1}$ to avoid tissue injury.

Pressure-volume data were analyzed by means of a segmented, non-linear regression model (model "PVD," Schulte and Hinckley 1985).

Bulk tissue osmotic potential, $\Psi_{\pi}$, was described by the function:

$$
\Psi_{\pi}=\frac{\Psi_{\pi, \text { sat }}}{1-\frac{1-\mathrm{RWC}}{\mathrm{SWF}}},
$$

where $\Psi_{\pi \text { sat }}$ is the osmotic potential at full tissue saturation, RWC is the relative water content and SWF is the symplastic fraction of the total water content. Bulk turgor potential, $\Psi_{\mathrm{p}}$, was described by the function:

$$
\Psi_{\mathrm{p}}=-\Psi_{\pi, \mathrm{sat}}\left(\frac{\mathrm{RWC}-\mathrm{RWC}_{\mathrm{tlp}}}{1-\mathrm{RWC}_{\mathrm{tlp}}}\right)^{b},
$$

where $\mathrm{RWC}_{\text {tlp }}$ is the relative water content at the turgor loss point and $b$ is a constant, both of which were estimated in the regression. Bulk modulus of elasticity, $\boldsymbol{\varepsilon}$, was then calculated as described by Jones and Turner (1980):

$$
\varepsilon=\frac{\mathrm{d} \Psi_{\mathrm{p}}}{\mathrm{dRSWC}},
$$

where RSWC is the relative symplastic water content and is calculated as:

$$
\mathrm{RSWC}=1-\frac{1-\mathrm{RWC}}{\mathrm{SWF}} \text {. }
$$

Differentiation of Equation 3 gives:

$$
\varepsilon=\frac{-\Psi_{\mathrm{p}} b}{\mathrm{RSWC}_{\mathrm{tlp}}-\mathrm{RSWC}},
$$

where $\mathrm{RSWC}_{\mathrm{tlp}}$ is the RSWC at the turgor loss point.

\section{Gas exchange measurements}

Net photosynthesis $\left(P_{\mathrm{N}}\right)$, stomatal conductance to water vapor $\left(g_{\mathrm{s}}\right)$, water use efficiency (WUE) and photosynthetically active radiation were determined with a portable gas exchange system (Li-Cor model LI-6200, Lincoln, NE). Measurements were taken between 1000 and $1500 \mathrm{~h}$ EDT on September 15, 1988. Cuvette air temperature ranged from 26 to $32{ }^{\circ} \mathrm{C}$. Leaf to air vapor pressure difference ranged 
from 2.1 to $5.7 \mathrm{kPa}$. Supplemental light from high intensity discharge lights was provided to ensure a minimum photosynthetically active photon flux of $1000 \mu \mathrm{mol}$ $\mathrm{m}^{-2} \mathrm{~s}^{-1}$. Measurements were taken on a block by block basis. Because WUE is highly sensitive to the leaf to air vapor pressure difference (Flore et al. 1985), an analysis of covariance was performed to evaluate differences in WUE at a common leaf to air vapor pressure difference. Measurements of transpiration rates inside a cuvette where the air is well stirred will tend to minimizc boundary-layer resistance. Thus, variation in WUE among treatments, measured within a cuvette, will typically represent differences in leaf anatomy and physiology more than leaf morphology.

Plant dry weights

Plants were harvested 30 days after the irrigation treatments commenced. Dry weights of harvested plants and abscised leaves (which were collected throughout the experiment) were determined after drying at $70^{\circ} \mathrm{C}$ for $96 \mathrm{~h}$.

\section{Results}

\section{Plant water relations}

Leaves of water-stressed plants showed a small decrease in $\Psi_{\text {tlp }}$ compared to well-watered plants (Table 1). The main-effect mean for $\Psi_{t \mathrm{p}}$ for well-watered plants

Table 1. Osmotic potential at full hydration $\left(\Psi_{\pi, \text { sat }}\right)$, total water potential at the turgor loss point $\left(\Psi_{\text {tp }}\right)$, relative symplastic water content at the turgor loss point $\left(\mathrm{RSWC}_{\mathrm{tlp}}\right)$, power exponent $(b)$, and the bulk modulus of elasticity at a turgor of 1.0 MPA $\left(\varepsilon_{1.0}\right)$ derived from pressure-volume measurements taken over the period of 20-30 days after irrigation treatments began.

\begin{tabular}{|c|c|c|c|c|c|}
\hline Treatments & $\begin{array}{l}\Psi_{\pi, \text { sat }} \\
(-\mathrm{MPa})\end{array}$ & $\begin{array}{l}\Psi_{\mathrm{tlp}} \\
(-\mathrm{MPa})\end{array}$ & $\mathrm{RSWC}_{\text {llp }}$ & $b$ & $\begin{array}{l}\varepsilon_{1.0} \\
(\mathrm{MPa})\end{array}$ \\
\hline \multicolumn{6}{|l|}{ Well-watered } \\
\hline Betula papyrifera & 1.08 & 1.33 & 0.82 & 1.38 & 8.32 \\
\hline Acer negundo & 1.34 & 1.54 & 0.87 & 1.35 & 13.34 \\
\hline Ulmus parvifolia & 1.30 & 1.61 & 0.81 & 1.38 & 9.15 \\
\hline Robinia pseudoacacia & 1.41 & 1.60 & 0.88 & 1.24 & 14.55 \\
\hline Malus baccata & 1.95 & 2.55 & 0.76 & 1.45 & 9.76 \\
\hline \multicolumn{6}{|l|}{ Water-stressed } \\
\hline Betula papyrifera & 1.18 & 1.45 & 0.81 & 1.39 & 8.48 \\
\hline Acer negundo & 1.34 & 1.62 & 0.84 & 1.66 & 12.97 \\
\hline Ulmus parvifolia & 1.61 & 2.02 & 0.80 & 1.38 & 9.88 \\
\hline Robinia pseudoacacia & 1.70 & 1.91 & 0.89 & 1.48 & 20.51 \\
\hline Malus baccata & 2.12 & 2.76 & 0.77 & 1.42 & 10.43 \\
\hline \multicolumn{6}{|l|}{ Factorial analysis ${ }^{1}$} \\
\hline Irrigation treatment & $* *$ & $* *$ & NS & $*$ & NS \\
\hline Species & $* *$ & $* *$ & $* *$ & NS & $* *$ \\
\hline Irrigation $\mathrm{x}$ species & $*$ & NS & NS & $*$ & NS \\
\hline $\mathrm{LSD}_{0.05}$ & 0.16 & 0.20 & 0.04 & 0.18 & 3.84 \\
\hline
\end{tabular}

${ }^{1} \mathrm{NS}, *{ }^{* *}$ nonsignificant or significant at the $5 \%$ or $1 \%$ level, respectively, $n=7$. 
was -1.73 MPa compared with -1.95 MPa for water-stressed plants, demonstrating a small but significant (main-effect contrast, $P<0.01$ ) increase in the capacity for water-stressed plants to maintain turgidity at more negative $\Psi_{\mathrm{w}}$. Differences among species were much greater, however, than differences between irrigation treatments. Under water-stressed conditions, leaves of $M$. baccata maintained $\Psi_{\mathrm{p}}$ to a $\Psi_{\mathrm{w}}$ of $-2.76 \mathrm{MPa}$ (Table 1). Robinia pseudoacacia and $U$. parvifolia had intermediate $\Psi_{\text {tlp }}$ values and $A$. negundo and B. papyrifera had the highest $\Psi_{\text {tp }}$ values.

Differences in $\Psi_{\text {up }}$ can result from variation in both $\Psi_{n \text {,sat }}$ and tissue elasticity (Tyree and Jarvis 1982). Acer negundo and B. papyrifera showed no significant decrease in $\Psi_{\pi, \text { sat }}$ (i.e., osmotic adjustment) in response to water stress, whereas $M$. baccata, $R$. pseudoacacia, and $U$. parvifolia showed significant decreases in $\Psi_{\pi, \text { sat }}$ of $0.17,0.29$, and $0.31 \mathrm{MPa}$, respectively (Table 1). Comparisons of $\Psi_{\pi, \text { sat }}$ among water-stressed plants showed that $M$. baccata had the most negative $\Psi_{\pi \text {,sat }}$ (Table 1). Robinia pseudoacacia and U. parvifolia had similar $\Psi_{\pi, \text { sat }}$ followed by $A$. negundo and B. papyrifera with the least negative $\Psi_{\pi \text {,sat }}$ values.

Variations in $\varepsilon$ as influenced by $\Psi_{\mathrm{p}}$ are shown in Figure 1. Because $\varepsilon$ is often a function of $\Psi_{\mathrm{p}}$ (Cheung et al. 1976, Roberts et al. 1981), $\varepsilon$ was calculated at a $\Psi_{\mathrm{p}}$ of $1.0 \mathrm{MPa}\left(\varepsilon_{1.0}\right)$. There was little effect of water stress on tissue elasticity of the species studied except in $R$. pseudoacacia (Table 1). Under conditions of water-stress, $\varepsilon_{1.0}$ varied from $8.48 \mathrm{MPa}$ for $B$. papyrifera (most elastic) to $20.51 \mathrm{MPa}$ for R. pseudoacacia (least elastic).

\section{Gas exchange}

Under well-watered conditions, the rate of light-saturated $P_{\mathrm{N}}$ ranged from 10.3 to 4.5 $\mu \mathrm{mol} \mathrm{m}{ }^{-2} \mathrm{~s}^{-1}$ for M. baccata and B. papyrifera, respectively (Table 2). Rates of $P_{\mathrm{N}}$ and $g_{\mathrm{s}}$ were much lower in all water-stressed plants and there were no significant differences among species under the water stress imposed (Table 2). Water use efficiency (adjusted for differences in vapor pressure difference) increased significantly in $A$. negundo and $M$. baccata in response to water stress ( $t$-test, $P<0.05$ ) (Figure 2). Comparisons among water-stressed plants showed that WUE of $M$. baccata was significantly higher than that of $B$. papyrifera or $U$. parvifolia. Acer negundo and $R$. pseudoacacia had intermediate WUE values that were not significantly different from those of the other species.

\section{Leaf and root weights}

Leaf/root dry weight ratios (LRR) are presented as an index of the balance between the capacitics for transpiration and absorption (Table 3). Betula papyrifera and $R$. pseudoacacia had lower LRR under water-stressed conditions than under wellwatered conditions. This difference may reflect an effect of water stress on dry matter partitioning, as well as on leaf abscission. In water stressed plants, LRR ranged from a low of 0.77 for R. pseudoacacia to 1.05 for B. papyrifera. 


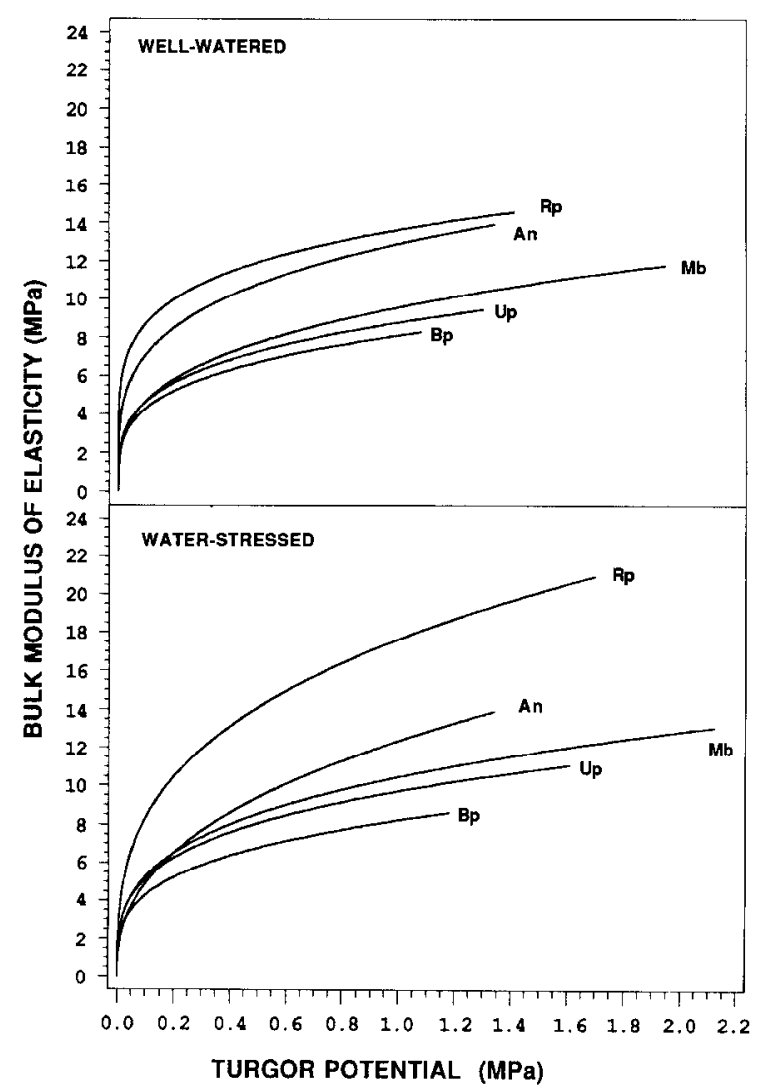

Figure 1. Bulk modulus of elasticity $(\varepsilon)$ of well-watered and water-stressed Acer negundo (An), Betula papyrifera $(\mathrm{Bp})$, Malus baccata (Mb), Robinia pseudoacacia $(\mathrm{Rp})$, and Ulmus parvifolia $(\mathrm{Up}) . \varepsilon$ was calculated as: $\left(b-\Psi_{\mathrm{p}}\right) /\left(\mathrm{RSWC}_{\mathrm{tp}}-\mathrm{RSWC}\right)$. See Table 1 for parameter estimates and statistical comparison of $\varepsilon$ at a turgor of $1.0 \mathrm{MPa}$.

\section{Discussion}

The tissue water potential at which turgor was lost $\left(\Psi_{\mathrm{t} p}\right)$ in water-stressed plants varied from $1.45 \mathrm{MPa}$ for $B$. papyrifera to 2.76 for $M$. baccata. Although a more elastic tissue (lower $\varepsilon$ ) will contribute to maintenance of turgor at low $\Psi_{w}$ (Tyree and Jarvis 1982), B. papyrifera (with the most elastic tissue, lowest $\varepsilon_{1.0}$ ) lost turgor at the least negative $\Psi_{\mathrm{w}}$. Because $\Psi_{\text {tpp }}$ is influenced by both $\varepsilon$ and $\Psi_{\pi \text {,sat }}$ this result shows that in B. papyrifera the effect of low $\varepsilon$ on $\Psi_{\text {tlp }}$ was more than offset by the influence of high $\Psi_{\pi \text {,sat. }}$ Furthermore, these results suggest that, for these species, $\Psi_{\text {tlp }}$ is influenced to a much greater degree by variation in $\Psi_{\pi \text {,sat }}$ than $\varepsilon$. This finding supports the supposition of Jones et al. (1985) that variation in $\varepsilon$ must be large before substantial changes in $\Psi_{\text {tlp }}$ result.

Malus baccata demonstrated the greatest turgor maintenance capacity, maintaining a positive $\Psi_{\mathrm{p}}$ to $-2.76 \mathrm{MPa} \Psi_{\mathrm{w}}$. This capacity resulted primarily from low $\Psi_{\pi \text {,sat }}$ (-2.12 MPa). Field studies of Malus domestica "MacIntosh" have shown $\Psi_{\pi \text {,sat }}$ 
Table 2. Net photosynthetic rate $\left(P_{\mathrm{N}}\right)$, stomatal conductance to $\mathrm{H}_{2} \mathrm{O}\left(g_{\mathrm{s}}\right)$, and tissue water potential $\left(\Psi_{\mathrm{w}}\right)$ measured 24 days after initiation of treatments.

\begin{tabular}{llll}
\hline Treatments & $\begin{array}{l}P_{\mathrm{N}} \\
\left(\mu \mathrm{mol} \mathrm{m} \mathrm{m}^{-2} \mathrm{~s}^{-1}\right)\end{array}$ & $\begin{array}{l}g_{\mathrm{s}} \\
\left(\mathrm{mol} \mathrm{m}^{-2} \mathrm{~s}^{-1}\right)\end{array}$ & $\begin{array}{l}\Psi_{\mathrm{w}} \\
(-\mathrm{MPa})\end{array}$ \\
\hline Well-watered & & & \\
Betula papyrifera & 4.7 & 0.10 & 0.81 \\
Acer negundo & 6.3 & 0.10 & 1.00 \\
Ulmus parvifolia & 8.1 & 0.14 & 0.89 \\
Robiniapseudoacacia & 5.4 & 0.06 & 0.95 \\
Malus baccala & 10.7 & 0.20 & 1.40 \\
Water-stressed & & & \\
Betula papyrifera & 0.9 & 0.01 & 1.18 \\
Acer negundo & 1.6 & 0.02 & 1.33 \\
Ulmus parvifolia & 2.0 & 0.02 & 1.72 \\
Robiniapseudoacacia & 2.0 & 0.02 & 2.33 \\
Malus baccata & 1.5 & 0.01 & 1.69 \\
\hline Factorial analysis & & & $* *$ \\
Irrigation treatment & $* *$ & $* *$ & $* *$ \\
Species & $* *$ & $* *$ & $* *$ \\
Irrigation $\times$ species & $* *$ & $* *$ & 0.33 \\
LSD 0.05 & 1.6 & 0.04 & \\
\hline
\end{tabular}

${ }^{1} \mathrm{NS}, *, * *$ nonsignificant or significant at the $5 \%$ or $1 \%$ level, respectively, $n=8$. Cuvette air temperature ranged from $26-32^{\circ} \mathrm{C}$, and leaf to air vapor pressure difference ranged from 2.1 to $5.7 \mathrm{kPa}$ over the measurement period. Light levels exceeded $1000 \mu \mathrm{mol} \mathrm{m}^{-2} \mathrm{~s}^{-1}$ for all mcasurcments.

\section{B. papyrifera}

U. parvifolia

A. negundo

R. pseudoacacia

M. baccata

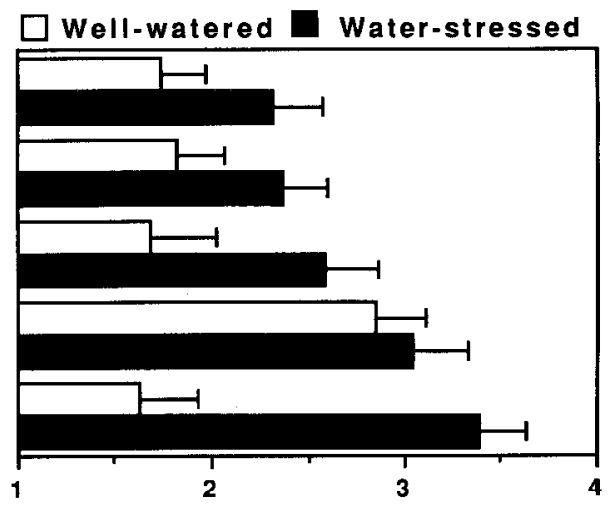

WATER USE EFFICIENCY $\left(\mu \mathrm{mol} \mathrm{CO}_{2} / \mathrm{mmol} \mathrm{H}_{2}\right.$ )

Figure 2. Instantaneous water use efficiency (net photosynthesis/transpiration) of well-watered and water-stressed Betula papyrifera, Ulmus parvifolia, Acer negundo, Robinia pseudoacacia, and Malus baccata. Values are least-square means $(n=8) \pm$ SEM. Mean leaf to air vapor pressure gradient was $3.8 \mathrm{kPa}$.

values ranging from $-2.00 \mathrm{MPa}$ (Davies and Lakso 1979) to -4.0 MPa (Lakso et al. 1984). The ability of $M$. baccata to maintain positive turgor under water stress did not result in greater $P_{\mathrm{N}}$ under the imposed water stress. Even though the $\Psi_{\text {tip }}$ for $M$. 
Table 3. Leaf/root dry weight ratios measured after 30 days of irrigation treatments and total weight of ahscised leaves collected throughout the experiment.

\begin{tabular}{lll}
\hline Treatments & Leaf/root dry weight ratio & Abscised leaf weight (g) \\
\hline Well-watered & & \\
B.papyrifera & 1.40 & 3.00 \\
A. negundo & 1.20 & 8.39 \\
U.parvifolia & 0.75 & 3.04 \\
R.pseudoacacia & 1.31 & 6.52 \\
M. baccata & 0.64 & 5.18 \\
Water-stressed & & \\
B.papyrifera & 1.05 & 15.67 \\
A. negundo & 0.98 & 7.09 \\
U.parvifolia & 0.77 & 4.49 \\
$R$. pseudoacacia & 0.60 & 38.73 \\
M. baccata & 0.86 & 4.74 \\
\hline Factorial analysis & & \\
Irrigation treatment & $* *$ & $* *$ \\
Species & $* *$ & $* *$ \\
Irrigation $\times$ species & $* *$ & $7 *$ \\
LSD 0.05 & 0.27 & 7.90 \\
\hline
\end{tabular}

${ }^{1} \mathrm{NS}, *, * *$ nonsignificant or significant at the $5 \%$ or $1 \%$ level, respectively, $n=8$.

baccata was $-2.8 \mathrm{MPa}$ (Table 1), which is considerably lower than the measured midday $\Psi_{\mathrm{w}}$ of $-1.7 \mathrm{MPa}$ (Table 2), $P_{\mathrm{N}}$ was reduced as a result of water stress, indicating that stress-induced reductions in $g_{\mathrm{s}}$ and $P_{\mathrm{N}}$ were due to factors other than loss of turgor. However, $M$. baccata has the potential to maintain $P_{\mathrm{N}}$ to a more negative $\Psi_{\mathrm{w}}$ than the other species. Lakso (1979) found that excised leaves of Malus domestica "McIntosh" maintained $P_{\mathrm{N}}$ to $\Psi_{\mathrm{w}}$ as low as $-5.0 \mathrm{MPa}$. The maintenance of $\Psi_{\mathrm{p}}$ and $P_{\mathrm{N}}$ at low $\Psi_{\mathrm{w}}$ coupled with a high WUE (cf. Flore et al. 1985) can be effective mechanisms for resisting water stress (Lakso 1983).

These adaptations may be particularly important for Malus spp. which are characterized by a low root density (Atkinson and Thomas 1985), a high resistance to water flow (Davies and Lakso 1978), and a low midday $\Psi_{\mathrm{w}}$ (Davies and Lakso 1978, 1979). Although depth of rooting in Malus spp. may exceed $2 \mathrm{~m}$, most of the root system is typically within the surface $0.5 \mathrm{~m}$ of soil (Atkinson and Thomas 1985), further limiting water availability during periods of drought.

Of the species examined, $U$. parvifolia and $R$. pseudoacacia were intermediate in their ability to maintain $\Psi_{\mathrm{p}}$ at low $\Psi_{\mathrm{w}}$. Furthermore, both of these species exhibited low leaf/root dry weight ratios (LRR) under water stress compared with the other species. The low LRR of $U$. parvifolia occurred under both well-watered and water-stressed conditions, suggesting that LRR is inherently low in this species. The low LRR of water-stressed plants of $R$. pseudoacacia resulted primarily from leaf abscission in response to the water stress. Leaf abscission greatly reduces transpiration and can be an important mechanism in avoiding the development of extreme 
water stress (Kozlowski 1976). In addition to low LRRs, Ulmus and Robinia can develop unusually deep roots. Bunger and Thomson (1938) found that $R$. pseudoacacia and Ulmus pumila (a close relative to $U$. parvifolia) have a maximum rooting depth exceeding $8 \mathrm{~m}$. These observations indicate that deep rooting and low LRR are both important mechanisms of drought resistance in $U$. parvifolia and $R$. pseudoacacia.

Acer negundo was intermediate in its capacity to maintain $\Psi_{\mathrm{p}}$ at low $\Psi_{\mathrm{w}}$ and in its LRR. Field studies have shown that the root system of $A$. negundo is very adaptable, being shallow and wide-spreading in alluvial soils, but very deep $(>4 \mathrm{~m})$, with a dominant taproot, on upland soils (Biswell 1935). Such morphological adaptability may account for the success of the species on dry sites.

Betula papyrifera had the lowest turgor maintenance capacity, the highest LRR under water stress and one of the lowest WUEs under water stress. The combination of these factors most likely contributes to the poor success of $B$. papyrifera on dry sites. Field studies have shown that $B$. papyrifera is shallow rooted (Pomerleau and Lortie 1962) with a mean rooting depth of only $0.5 \mathrm{~m}$ in mature trees.

Success of plants growing on dry sites results from the integration of characteristics that contribute to stress tolerance at both high and low tissue $\Psi_{\mathrm{w}}$. However, the effectiveness of any combination of traits in conferring drought resistance is dependent on environmental conditions. Potential for deep rooting, as with $R$. pseudoacacia and $U$. parvifolia, would contribute little to drought resistance where soils are shallow or root systems are confined. In such cases, turgor maintenance at low $\Psi_{w}$ and high WUE, as with $M$. baccata, may be of particular importance in conferring resistance to drought. Alternatively, where soils are deep and welldrained, plants with lower LRR and deep rooting habits may be better adapted to drought.

The varicty of plant characteristics that contribute to drought resistance and the variation in site characteristics makes plant selection for dry sites difficult. A greater understanding of the physiology, adaptive characteristics, and response to water stress of different species will enhance our ability to select more appropriate species and genotypes for specific sites.

\section{References}

Atkinson, D. and C.M.S. Thomas. 1985. The influence of cultural methods on the water relations of fruit trees. Acta Hort. 171:371-382.

Biswell, H.H. 1935. Effects of environment upon the root habits of certain deciduous forest trees. Bot. Gaz. 96:676-708.

Bunger, M.T. and H.J. Thomson. 1938. Root development as a factor in the success or failure of windbreak trees in the southern high plains. J. For. 36:790-803.

Cheung, Y.N.S., M.T. Tyree and J. Dainly. 1976. Some possible sources of error in determining bulk moduli and other parameters from pressure-volume curves of shoots and leaves. Can. J. Bot. 54:758-765.

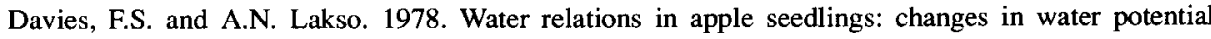
components, abscisic acid levels and stomatal conductances under irrigated and non-irrigated conditions. J. Amer. Soc. Hort. Sci. 103:310-313. 
Davies, F.S. and A.N. Lakso. 1979. Diurnal and seasonal changes in leaf water potential components and elastic properties in response to water stress in apple tress. Physiol. Plant. 46:109-114.

Dewers, R.S. 1981. Evaluation of native and exotic woody plants under severe environmental stress. J. Arboric. 7:229-302.

Dirr, M.A. and A.E. Richard. 1989. In search of the perfect Chinese elm. Amer. Nurseryman 169:37-49.

Flint, H.L. 1985. Plants showing tolerance to urban stress. J. Env. Hort. 3:85-89.

Flore, J.A., A.N. Lakso and J.W. Moon. 1985. The effect of water stress and vapor pressure gradient on stomatal conductance, water use efficiency, and photosynthesis of fruit crops. Acta Hort. 171:207218.

Hatton, J.H. 1935. A review of early tree-planting activity in the plains region. In Possibilities of Shelterbelt Planting in the Plains Region. Lake States For. Exp. Sta, USFS, WA, pp 51-57.

Hinckley, T.M., F. Duhme, A.R. Hinckley and H. Richter. 1980. Water relations of drought hardy shrubs: osmotic potential and stomatal reactivity. Plant, Cell Environ. 3:131-140.

Jones, H.G. 1980. Interaction and integration of adaptive responses to water stress: the implications of an unpredictable environment. In Adaptation of Plants to Water and High Temperature Stress. Eds. N.C. Turner and P.J. Kramer. Wiley, New York, pp 353-365.

Jones, H.G., A.N. Lakso and J.P. Syvertsen. 1985. Physiological control of water status in temperate and subtropical fruit trees. Hort. Rev. 7:301-344.

Jones, M.M. and N.C. Turner. 1980. Osmotic adjustment in expanding and fully expanded leaves of sunflower in response to water deficits. Aust. J. Plant Physiol. 7:181-192.

Kozlowski, T.T. 1976. Water supply and leaf shedding. In Water Deficits and Plant Growth. IV. Ed. T.T. Kozlowski. Academic Press, New York, pp 191-231.

Lakso, A.N. 1979. Seasonal changes in stomatal response to leaf water potential in apple. J. Amer. Soc. Hort. Sci. 104:58-60.

Lakso, A.N. 1983. Morphological and physiological adaptations for maintaining photosynthesis under water stress in apple trees. In Effect of Stress on Photosynthesis. Eds. R. Marcelle, H. Clijsters and M. van Poucke. Nijhoff/Junk, The Hague, pp 85-93.

Lakso, A.N., A.S. Geyer and S.G. Carpenter. 1984. Seasonal osmotic relations in apple leaves of different ages. J. Amer. Soc. Hort. 109:544-547.

Pomerleau, R. and M. Lortie. 1964. Relationships of dieback to the rooting depth of white birch. For. Sci. 8:219-224.

Ritchie, G.A. and J.R. Roden. 1985. Comparison between two methods of generating pressure-volume curves. Plant, Cell Environ. 8:49-53.

Roberts, S.W., B.R. Strain and K.R. Knoerr. 1981. Seasonal variation of leaf tissue elasticity in four forest tree species. Physiol. Plant. 52:245-250.

Schulte, P.J. and T.M. Hinckley. 1985. A comparison of pressure-volume curve data analysis techniques. J. Exp. Bot. 36:1590-1602.

Turner, N.C. 1979. Drought resistance and adaptation to water deficits in crop plants. In Stress Physiology in Crop Plants. Eds. H. Mussel and R.C. Staples. Wiley, New York, pp 343-372.

Tyree, M.T. and H.T. Hammel. 1972. The measurement of the turgor pressure and the water relations of plants by the pressure-bomb technique. J. Exp. Bot. 23:267-282.

Tyree, M.T. and P.G. Jarvis. 1982. Water in tissues and cells. In Encyclopedia of Plant Physiology. 12B. Eds. O.L. Lange, P.S. Nobel, C.B. Osmond and H. Ziegler. Springer-Verlag, New York, pp 542-546. 